\title{
Al-Chizan
}

Jurnal Pemikiran Hukum Islam

ISSN 1907-0985, E ISSN 2442-8256

Vol. 15, No. 1, 2019, h. 127-154

DOI: https://doi.org/10.30603/am.v15i1.975

\section{Kritik atas Fikih Lintas Agama: Studi atas Pemikiran Kaum Revivalis}

\section{Siti Hardianti Liputo, Sofyan A.P. Kau}

Pascasarjana IAIN Sultan Amai Gorontalo

Email: Sitihardianti804@gmail.com; sofyan.ap.kau@gmail.com

Abstract: This paper explains the revivalist Islamic criticism of the views of the Paramadina Writers Team which permits interfaith marriages and permissibility of inheritance of different religions. This research is a library research with the main data source is the book Fiqh Lintas Agama: Membangun Masyarakat Inklusif-Pluralis. The results showed that Islamic revivalists argued that the history of Mu'azd and Muawiyah which was used as a reference by the Paramadina Writers Team did not agree on its validity compared to the history which forbids a Muslim from inheriting infidels. Whereas giving precedence to an agreed proposition of validity is more important to be held against than an argument whose validity is not agreed upon. Choosing a majority opinion over the opinion of a minority is more prioritized. The case where the majority of scholars forbid interfaith marriages is haram because of the textual statements of the verse, except marriages with the ahl al-kitab. That skill is also an emergency. Even the adverse effects of interfaith marriages must take precedence over benefits.

Keywords: Fiqh Lintas Agama, Revivalists, Marriage, Inheritance

\section{Criticism of Fiqh Lintas Agama: Study of Thought Revivalists}

\begin{abstract}
Abstrak: Tulisan ini mengungkap kritik Islam revivalis atas pandangan Tim Penulis Paramadina yang membolehkan perkawinan beda agama dan kebolehan atas waris beda agama. Penelitian ini adalah penelitian pustaka dengan sumber data utama adalah buku Fiqh Lintas Agama Membangun Masyarakat Inklusif-Pluralis. Hasil penelitian menunjukkan bahwa Islam revivalis berargumen bahwa riwayat $\mathrm{Mu}$ 'az dan Muawiyah yang dijadikan rujukan oleh Tim Penulis Paramadina tidak disepakati kevalidannya
\end{abstract}


Kritik atas Fikih Lintas Agama: Studi atas Pemikiran

Kaum Revivalis

dibandingkan dengan riwayat yang melarang seorang muslim mewarisi orang kafir. Sedangkan mendahulukan dalil yang disepakati kevalidannya adalah lebih utama diperpegangi daripada dalil yang tidak disepakati kevalidannya. Memilih pendapat mayoritas atas pendapat minoritas jauh lebih dikedepankan. Hal mana mayoritas ulama melarang nikah beda agama adalah haram karena pernyataan tekstual ayat, kecuali nikah dengan ahl alkitab. Itu pun kebolehan tersebut bersifat darurat. Bahkan dampak buruk perkawinan beda agama harus didahulukan daripada mengambil manfaat.

Kata Kunci: Fikih Lintas Agama, Kaum Revivalis, Perkawinan, Kewarisan

\section{A. Pendahuluan}

Fikih lintas agama adalah hasil pemikiran cendekiawan muslim dibidang hukum Islam yang terkait dengan isu-isu non muslim. Istilah teknis fikih lintas agama tidak ditemukan dalam diskursus fikih klasik. Terminologi fikih lintas agama pertama kali diperkenalkan oleh Tim Penulis Paramadina dengan hadirnya buku Fiqh Lintas Agama Membangun Masyarakat Inklusif-Pluralis. ${ }^{1}$ Meskipun demikian, pandangan ulama fikih tentang hal-hal yang berkaitan dengan agama di luar Islam dibahas di dalam fikih. Hanya saja hubungan agama-agama dalam perspektif ulama fikih klasik berbeda dengan pandangan pemikiran Tim Penulis Paramadina.

Salah satu opini hukum fiqh lintas agama yang berseberangan adalah nikah beda agama. Mayoritas ulama mengharamkan pernikahan seorang muslim/muslimah dengan seorang non muslim, baik non muslim dalam kategori ahlul kitab maupun musyrik/musyrikah. Keharaman ini didasarkan pada QS al-Baqarah/2: 221 dan al-Maidah/5: 5. Sebaliknya fiqh lintas agama membolehkan seorang yang beragama Islam menikah dengan seseorang di luar Islam. Kebolehan tersebut didasarkan kepada pernyataan QS alMaidah/5: 5 yang menegaskan: "(dan dihalalkan mangawini) wanita yang menjaga kehormatan di antara wanita-wanita yang beriman dan wanita-

${ }^{1}$ Buku Fiqh Lintas Agama Membangun Masyarakat Inklusif-Pluralis diterbitkan oleh Yayasan Wakaf Paramadina bekerjasama dengan The Asia Foundation, tahun 2004. Buku yang dieditori oleh Mun'im A. Sirri ditulis oleh Tim Penulis Paramadina, yaitu: Zainun Kamal, Nurcholish Madjid, Masdar F. Mas'udi, Komaruddin Hidayat, Budhy Munawar Rachman, Kautsar Azhari Noer, Zuhairi Misrawi dan Ahmad Gaus AF. 
wanita yang menjaga kehormatan di antara orang-orang yang diberi alKitab sebelum kamu'. Kebolehan ini dipahami oleh fiqh lintas agama bukan bersifat sementara, sebagaimana dipahami oleh kebanyakan ulama fikih. Demikian juga, larangan menikah dengan kelompok musyrik dalam QS alBaqarah/2: 221 sebagai dasar teologis pelarangan nikah beda agama, justru dipahami oleh fiqh lintas agama sebagai larangan yang bersifat politis. Bahwa pelarangan itu disebabkan ketidakharmonisan hubungan kaum muslimin ketika itu dengan kaum musyrik Mekah. Kaum musyrik Mekah memusuhi kaum muslimin. Karena itu, sebagai sanksi sosial, kaum muslimin dilarang menikah dengan kaum musyrik Mekah. Jika hubungan dengan kaum musyrik telah baik, maka pelarangan itu tidak relevan lagi dijadikan alasan at as pengharaman menikah dengan mereka.

Selain hal itu dalam diskursus fikih kewarisan disebutkan bahwa seorang muslim tidak dapat saling mewarisi dengan non muslim. Itu berarti, non muslim tidak berhak atas harta warisan dari seorang muslim. Ditegaskan dalam fikih waris, bahwa syarat untuk memperoleh kewarisan adalah Islam. Karena itu, meskipun memiliki hubungan darah dan ikatan perkawinan, namun jika tidak seagama (baca: Islam), maka tidak akan memperoleh warisan. Argumen yang dijadikan dasar atas pelarangan tersebut adalah hadis Nabi saw.: "Seorang muslim tidak mewarisi kepada orang-orang kafir, dan orang kafir juga tidak mewarisi kepada orang muslim". ${ }^{2}$ Berdasarkan landasan normatif ini, ulama berkesimpulan bahwa terlarang dan haram waris beda agama. ${ }^{3}$ Pandangan ini dinilai oleh fiqh lintas Agama sebagai fikih yang sangat tidak toleran terhadap agama lain. ${ }^{4}$ Dalam pandangan fiqh lintas agama, perbedaan teologis tidak menjadi halangan bagi non muslim untuk memperoleh hak kewarisan baik menerima warisan maupun mewarisi.

Pemikiran fikih lintas agama tentang nikah dan waris beda agama di atas menuai kritik dari kelompok Islam revivalis; suatu kelompok yang menurut Siti Musdah Mulia lebih menekankan aspek fikih dan memandang fikih sebagai perwujudan dari teologi. ${ }^{5}$ Itu berarti, kelompok ini sangat fikih oriented. Fikih oriented kaum revivalis ini terlihat jelas dari kritik dan

${ }^{2}$ Al-Shan'ânî, Subul al-Salâm, Juz III (Bandung: Dahlan, t.th.), 101.

${ }^{3}$ Ibnu Rusyd, Bidayah al-Mujtahid wa Nihayah al-Muqtashid, Jil. II (Beirut: Dar alFikr, t.th.), 264.

${ }^{4}$ Nurcholish Madjid, et. al., Fiqh Lintas Agama Membangun Masyarakat InklusifPluralis, (Jakarta: Yayasan Wakaf Paramadina - The Asia Foundation, 2004), 165.

${ }^{5}$ Siti Musdah Mulia, Islam dan Inspirasi Kesetaraan Gender (Yogyakarta: Kibar Press, 2007), 45-46. 
Kritik atas Fikih Lintas Agama: Studi atas Pemikiran

Kaum Revivalis

kecaman mereka terhadap fiqh lintas agama. Hartono Ahmad Jaiz dalam kata pengantar buku Koreksi Total Fiqh Lintas Agama menyebut isi buku Fikih Lintas Agama berseberangan dengan Islam. ${ }^{6}$ Irfan Suryahardi Awwas Ketua Lajnah Tanfiziyah Majlis Mujahidin dalam sambutan "Debat Publik Bedah Buku Fikih Lintas Agama" menyebut fikih lintas agama sebagai bentuk kekafiran berpikir. ${ }^{7}$

Kritik kaum revivalis menarik untuk dikaji bukan karena kecaman mereka terhadap fikih lintas agama dan person para penulisnya. Yang menarik penulis adalah argumen dan dasar-dasar metodologi yang mereka bangun dalam meng- counter fikih lintas agama. Karena itu, tulisan ini akan diarahkan kepada aspek metodologi penetapan hukum fikih tentang relasi agama sehingga posisi dasar dan kekuatan metode yang digunakan oleh kaum revivalis dapat didudukkan secara obyektif. Pada saat yang sama juga, akan terlihat pula basis argumen teologis fikih lintas agama dan kaum revivalis secara adil.

\section{B. Perspektif Fikih Lintas Agama tentang Perkawinan Beda Agama}

Perkawinan beda agama adalah perkawinan beda agama antara lakilaki atau perempuan beragama Kristen dengan laki-laki atau perempuan yang beragama Islam, dan lain sebagainya. ${ }^{8}$ Eoh O.S. mendefinisikan perkawinan beda agama sebagai perkawinan yang dilakukan oleh antara dua orang yang berbeda agama dan masing-masing tetap mempertahankan agamanya. ${ }^{9}$ Menurut Islamiyati, perkawinan beda agama adalah perkawinan yang dilakukan oleh pasangan yang berbeda agama atau keyakinannya. ${ }^{1010}$ Dengan demikian perkawinan beda agama adalah perkawinan antara dua orang yang berbeda agama dan masing-masing tetap mempertahankan agama yang dianutnya. Itu berarti, perkawinan beda agama bisa dalam

${ }^{6}$ Hartono Ahmad Jaiz, "Kata Pengantar" dalam Agus Hasan Bashori, Koreksi Total Fiqh Lintas Agama Membongkar Kepalsuan Paham Inklusif-Pluralis (Jakarta: Pustaka AlKautsar, 2004), vii.

${ }^{7}$ Tim Editor Mujahidin, Kekafiran Berpikir Sekte Paramadina (Jakarta: Wihdah Press, 2004), 33.

${ }^{8}$ Hilman Hadikusuma, Hukum Perkawinan Indonesia Menurut Perundangan, Hukum Adat, Hukum Agama (Bandung: Mandar Maju, 1990), 13-14.

${ }^{9}$ Eoh O.S. Perkawinan Beda Agama dalam Teori dan Praktek (Jakarta: Raja Grafindo Persada,1996), 36.

${ }^{10}$ Islamiyati, "Analisis Yuridis Nikah Beda Agama Menurut Hukum Islam di Indonesia,” Masalah-Masalah Hukum, Jilid 45 No. 3, Juli 2016, 243-25. 
bentuk laki-laki muslim mengawini wanita non muslim dan atau sebaliknya, wanita muslimah dikawini oleh laki-laki non muslim. Dua bentuk perkawinan yang disebut terakhir belakangan disebut perkawinan lintas agama atau perkawinan antar agama.

Istilah perkawinan beda agama dalam diskursus fikih tidak dikenal. Sebab perkawinan beda agama lebih menekankan perkawinan yang dilakukan oleh mereka yang menganut agama secara formal. Di Indonesia, terdapat enam agama yang diakui secara formal, yaitu Islam, Kristen, Katolik, Hindu, Budha dan Kong $\mathrm{Hu} \mathrm{Cu}$. Sementara dalam fikih, perkawinan dapat dilakukan oleh mereka yang menganut agama Islam dengan yang tidak menganut agama Islam. Dalam al-Quran, perkawinan beda agama terdiri at as tiga bentuk, yaitu perkawinan dengan ahlul al- Kitâb (QS al-Mâidah/5: 5); perkawinan dengan musyrik (QS al-Baqarah/2: 221); dan perkawinan dengan kafir (QS al-Mumtahanah/60:10).

Menurut fikih lintas agama perkawinan beda agama adalah boleh berdasarkan makna tekstual QS al-Mâidah/5: 5, yaitu: "Pada hari ini dihalalkan bagimu yang baik-baik, makanan (sembelihan) orang-orang yang diberi al-Kitab itu halal bagimu, dan makanan kamu halal (pula) bagi mereka. (Dan dihalalkan mangawini) wanita yang menjaga kehormatan di antara wanita-wanita yang beriman dan wanita-wanita yang menjaga kehormatan di antara orang-orang yang diberi al-Kitab sebelum kamu, bila kamu telah membayar mas kawin mereka dengan maksud menikahinya, tidak dengan maksud berzina dan tidak (pula) menjadikannya gundikgundik. Barangsiapa yang kafir sesudah beriman (tidak menerima hukumhukum Islam), maka hapuslah amalannya dan ia di hari kiamat termasuk orang-orang merugi”. Menurut Tim Penulis Paramadina, konsep ahl al-kitâb menunjukan sekurang-kurangnya sebagai penegasan bahwa Islam datang paling akhir dari deretan agama-agama abrahmic memberikan pengakuan secara terbuka bahwa sejumlah kitab yang turun kepada para nabi dan rasul sebelum Muhammad saw. adalah sah dan valid, sehingga dapat dijadikan referensi bagi umat yang membaca dan mengimaninya. Menurut Abd. Moqsith Ghazali, al-Quran datang untuk membenarkan prinsip-prinsip dasar ajaran tauhid yang telah diletakkan oleh para nabi dan rasul sebelumnya, seperti Ibrâhîm, Mûsâ, 'Îsâ dan sebagainya. ${ }^{11}$ Salah satu bentuk pengakuan

${ }^{11}$ M. Quraish Shihab, Tafsir al-Mishbah, Vol. 3 (Jakarta: Lentera Hati, 1421 H/2001 M). 28-30. Lihat juga Muhammad Quraish Shihab, Anda Bertanya M. Quraish Shihab Menjawab Berbagai Masalah Keislaman (Bandung: Al-Bayan, 2002), 220-222. 
Kritik atas Fikih Lintas Agama: Studi atas Pemikiran

Kaum Revivalis

itu adalah kebolehan menikahi perempuan mereka sebagaimana ditegaskan dalam QS al-Mâidah/5: 5. Kebolehan tersebut bersifat mutlak, dan karena itu keberlakuannya tidak terbatas sebelum turunnya al-Quran. Dengan ungkapan lain, Tim Penulis Paramadina memperluas cakupan makna ahl alkitâb.

Menurut Nurcholish Madjid (w. 2005 M) sebutan ahl al-kitâb tertuju kepada golongan bukan Muslim, dan tidak ditujukan kepada kaum Muslim, meskipun mereka menganut kitab suci al-Quran. ${ }^{12}$ Ahl al-kitâb tidak tergolong kaum Muslim, karena mereka tidak mengakui atau bahkan menentang kenabian dan kerasulan Muhammad saw. dan ajarannya. Oleh karena itu, dalam terminologi al-Quran disebut kafir, yakni "yang menentang" atau "yang menolak," dalam hal ini menentang atau menolak Nabi Muhammad Saw. dan ajaran beliau, yaitu ajaran agama Islam. Sebagai kelompok yang menentang atau menolak Nabi, kaum Yahudi dan Nasrani mempunyai sikap yang berbeda-beda, ada yang keras da nada pula yang lunak. Karena itu, Nurcholish berpendapat ahl al-kitâb tidak tergolong musyrik. ${ }^{13}$ Bahkan kelompok agama lain, seperti Majusi (Zoroaster) dan Sâbi"în termasuk ahl al-kitâb. ${ }^{14}$ Nurcholish mendasarkan pendapatnya kepada Ibnu Taimiyah (w. $728 \mathrm{H} / 1328 \mathrm{M}$ ) yang berpendapat kaum ahl alkitâb bukan termasuk musyrik, dan Muhammad Rasyîd Ridhâ yang menegaskan bahwa di luar kaum Yahudi dan Nasrani juga terdapat ahl alkitâb, seperti Hindu, Budha dan Konfusius (Konghucu). ${ }^{15}$

Pendapat Nurcholish tersebut menunjukkan cakupan makna ahl alkitâb tidak terbatas kepada kaum Yahudi dan Nasrani, tetapi juga kepada agama lain selain Yahudi dan Nasrani. Pendapat senada juga dikemukakan Zainun Kamal yang berpendapat seseorang yang percaya kepada salah satu nabi dapat dikategorikan ahl al-kitâb, termasuk agama-agama yang diakui di Indonesia. Zainun Kamal mendasarkan pendapatnya kepada pemikiran alBagdâdî dan Muhammad Abduh. Al-Bagdâdî memasukkan agama Majusi atau Zoroaster yang ada di sekitar Arab sebagai ahl al-kitâb. Bahkan Ibnu

${ }^{12}$ Nurcholish Madjid, Islam Agama Peradaban Membangun Makna dan Relevansi Doktrin Islam dalam Sejarah (Jakarta: Paramadina, 1995), 70-71.

${ }^{13}$ Nurcholish Madjid, Islam Agama Peradaban, 74.

${ }^{14}$ Nurcholish Madjid, Islam Agama Peradaban, 80.

${ }^{15}$ Nurcholish Madjid, Islam Agama Peradaban, 78 dan 81. Bandingkan Ibnu Taimiyah, Ahkam al-Zawâj (Beirût: Dâr al-Kutub al-Ilmiyyah, 1408H/1988 M), 188-190 dan Muhammad Rasyîd Ridhâ, Tafsîr al-Qur" ân al- $\underline{H}$ akîm, Juz VI (Beirût: Dâr al- Kutub al'Ilmiyyah, 1999 M), 188-189. 
Rusyd (w. $582 \mathrm{H}$ ) menyebut Aristoteles sebagai seorang nabi. Muhammad Abduh (w. 1323 H) dalam Tafsîr al-Manâr menyebut agama Budha, Hindu, atau agama Konghucu dan Shinto sebagai ahl al-kitâb, karena ada kitab suci yang dibawa oleh seorang nabi. Nabi diartikan sebagai pembawa pesan moral. Di dalam Al-Quran disebutkan "Allah mengutus kepada setiap umat seorang rasul." Budha, Sidharta Gautama dapat digolongkan sebagai nabi yang membawa kitab suci. Berdasarkan pengertian dan cakupan ahl al-kitâb tersebut, Zainun Kamal berpendapat bahwa tidak ada larangan menikah dengan kaum agama lain, seperti agama Hindu, Budha, Kristen dan Protestan. Sebab, mereka juga mempunyai kitab suci yang berisi pesan moral dan menjadi pegangan hidup. ${ }^{17}$ Tim Penulis Paramadina berkesimpulan bahwa konsep ahl al-kitâb menunjukan pengakuan kepada para penganut agama di luar Islam yang memiliki kitab suci. Karena itu, istilah ahlul Kitâb tidak tertuju kepada Muslim, sekalipun memiliki kitab suci. ${ }^{18}$ Tegasnya, kriteria ahlul Kitâb dalam perspektif Tim Penulis Paramadina adalah mereka yang memiliki kitab suci, apa pun agama dan kepercayaannya.

Berdasarkan QS al-Maidah/5: 5 bahwa kebolehan itu berlaku atas perkawinan laki-laki muslim dengan wanita ahl al-kitâb, sedangkan sebaliknya bentuk perkawinan wanita muslimah dengan laki-laki ahl al-kitâb tidak ditegaskan oleh teks. Tim Penulis Paramadina selain membolehkan laki-laki muslim menikah dengan ahl al-kitâb, mereka juga menghalalkan pernikahan wanita muslim dengan laki-laki ahl al-kitâb.

Adapun bentuk perkawinan kedua, yaitu perkawinan dengan orang musyrik ditegaskan dalam QS. al-Baqarah/2: 221: "Dan janganlah kamu menikahi perempuan-perempuan musyrik, sebelum mereka beriman. Sesungguhnya perempuan budak yang mukmin lebih baik dari perempuan musyrik, walaupun dia menarik hatimu. Dan janganlah kamu menikahkan orang-orang musyrik (dengan perempuan- perempuan mukmin) sebelum mereka beriman. Sesungguhnya budak yang mukmin lebih baik dari orang musyrik, walaupun dia menarik hatimu. Mereka mengajak ke neraka, sedang Allah mengajak ke surga dan ampunan dengan izin-Nya. Dan Allah

\footnotetext{
${ }^{16}$ Lihat QS al-Nahl/16: 36.

${ }^{17}$ Zainun Kamal, "Menafsir Kembali Perkawinan Antar Umat Beragama" dalam Maria Ulfah Anshor dan Martin Lukito Sinaga (eds.), Tafsir Ulang Perkawinan Lintas Agama Perspektif Perempuan dan Pluralisme (Jakarta: Kapal Perempuan, 2005), 154.

${ }^{18}$ Nurcholish Madjid, et.al. Fiqih Lintas Agama, 43.
} 
Kritik atas Fikih Lintas Agama: Studi atas Pemikiran

Kaum Revivalis

menerangkan ayat-ayat-Nya (perintah-perintah-Nya) kepada manusia supaya mereka mengambil pelajaran".

Berdasarkan makna literal ayat tersebut, mayoritas ulama berpendapat haram menikah dengan kaum musyrik. Demikian pula sebaliknya. Tidak ada perbedaan pendapat di kalangan ulama tentang larangan menikah dengan kaum musyrik. ${ }^{19}$ Dalam pemahaman Tim Penulis Paramadina, wanita musyrik yang haram dikawini oleh orang-orang Islam adalah bukan hanya mempersekutukan Allah tapi juga tidak mempercayai salah satu dari kitab-kitab Samawi, baik yang telah terdapat penyimpangan ataupun yang masih asli; disamping tidak seorang Nabipun mereka percayai. ${ }^{20}$ Dengan kategori yang disebut terakhir, Zainun Kamal, salah seorang Tim Penulis Paramadina, -memasukkan orang-orang Majusi dan Sabian kelompok ahl al-Kitâb. Sebab orang-orang Majusi mempercayai kenabian Zoroaster dan Allah, menurunkan wahyu kepadanya sebagai kitab suci yang bernama Zend Avesta, dan orang-orang beragama Sabian memiliki kitab suci bernama Ginza, percaya terhadap Hernes, Plato dan beberapa filosuf mendapatkan wahyu Samawi dari Allah yang ajarannya mengandung perintah larangan, surga, dan neraka. Oleh karena itu, Ibnu Rusyd menggolongkan Aristoteles seorang filosuf Yunani sebagai seorang manusia yang bersifat Ilâhî (seorang Nabi) karena ketinggian ajaran mereka, terutama ajaran moral dan bersesuaian dengan ajaran agama. ${ }^{21}$

Atas dasar itu Tim Penulis Paramadina membedakan musyrik dan ahl $a l-k i t a ̂ b$, sebab al-Quran sendiri tidak memberikan kriteria khusus siapa sebenarnya musyrikah itu. ${ }^{22}$ Karena itu ulama berbeda pendapat, ada yang mengkategorikan ahl al-kitâb termasuk musyrik atau musyrik bukan termasuk ahlul Kitâb seperti pendapat Abdullah ibnu 'Umar dan yang tidak menggolongkan musyrik sebagai ahl al-kitâb. Menurut Nurcholish Madjid, pandangan kedua adalah pandangan yang banyak dianut ulama. Nurcholish termasuk yang berpendapat bahwa ahl al-kitâb tidak tergolong musyrik. Pandangan Nurcholish didasarkan atas pendapat Ibnu Taimiyah dan Muhammad Rasyîd Ridhâ yang menyatakan bahwa kaum ahl al-kitâb bukan

${ }^{19}$ Amir Syarifuddin, Hukum Perkawinan Islam di Indonesia (Kencana Prenada Media Group, Jakarta, 2009), 133.

${ }^{20}$ Nurcholish Madjid, et.al. Fiqih Lintas Agama, 159.

${ }^{21}$ Jamîl Shâliba, Min Aflatan ilâ Ibn Sînâ (Beirût: Dâr al-Andalus, 1981), 47.

${ }^{22}$ Budy Munawar-Rachman, Reorientasi Pembaruan Islam: Sekularisme, Liberalisme \& Pluralisme Paradigma Baru Islam Indonesia (Jakarta: LSAF, 2010), 710-712. 
termasuk musyrik. ${ }^{23}$ Perbedaan ahl al-kitâb dengan musyrik adalah ajaran monotheisme. Musyrik sepertinya murni sebagai kekuatan politik, sedangkan ahl al-kitâb (Yahudi dan Kristen) adalah mereka yang sedikit banyak mempunyai persinggungan teologis dengan Islam. ${ }^{24}$ Oleh karena itu, dalam perspektif Zainun Kamal, tidak setiap perbuatan syirik menjadikan pelakunya secara langsung disebut musyrik, karena pada kenyataannya Yahudi dan Nasrani telah melakukan perbuatan syirik, namun Allah tidak menyebut dan memanggil mereka sebagai musyrik, namun tetap dipanggil dengan ahl al-kitâb. Hal ini dapat dilihat dalam QS al-Nisâ/4: 171, QS alMâidah/5: 5 dan QS Âli 'Imrân/3: 64. Orang-orang Islam pun bisa melakukan perbuatan syirik, dan memang kenyataannya ada, namun mereka tidak dapat disebut sebagai kaum musyrik. Sebab sebagai konsekuensi logisnya, jika salah seorang suami-istri dari keluarga Muslim sudah disebut musyrik, maka perkawinan mereka batal (fasakh) dengan sendirinya dan mereka wajib cerai, tapi kenyataan ini tidak pernah diterima. Betapa banyak terdapat dalam kenyataan hidup ini pada orang-orang beragama, termasuk orang-orang Muslim, melakukan perbuatan syirik dalam kehidupan sehariharinya seperti orang yang mempertaruhkan hawa nafsunya. ${ }^{25}$

Argumen teologis yang dikemukakan Tim Penulis Paramadina tentang ketidaksamaan antara musyrik dengan ahl al-kitâb adalah QS alBaqarah/2: 105, yaitu: "Orang-orang kafir dari ahlul Kitâb dan orang-orang Musyrik tidak menginginkan diturunkan nya suatu kebaikan kepadamu dari Tuhanmu..." dan QS al-Bayyinah/98: 1, yaitu "Orang-orang kafir dari ahlul Kitâb dan orang-orang kafir Musyrik tak akan melepaskan (kepercayaan mereka) sampai datang kepada mereka bukti yang nyata." Kedua ayat menunjukan dua kategori orang kafir, yaitu ahl al-kitâb dan musyrik (kafir ahl al-kitâb dan kafir musyrik). Di dalam kedua ayat tersebut, al-Quran menggunakan kata penghubung "dan"e antara kata kafir ahl al-kitâb dan kafir musyrik. Hal ini menunjukkan dua makna, yaitu: Pertama, ahl al-kitâb berbeda dengan musyrik; Kedua, kata kafir mencakup makna yang luas yang di dalamnya terdapat istilah-istilah yang lebih khusus dengan arti dan makna berbeda antara satu dengan lainnya. Oleh karena itu, kalau al-Quran menyebut terma kafir musyrik, maka makna atas terma ini berbeda dengan terma kafir ahl al-kitâb.

${ }^{23}$ Nurcholish Madjid, Islam Agama Peradaban Membangun Makna dan Relevansi Doktrin Islam dalam Sejarah (Jakarta: Paramadina, 1995), 74, 79.

${ }^{24}$ Nurcholish Madjid, et.al., Fiqih Lintas Agama, 160-161.

${ }^{25}$ Nurcholish Madjid, et.al., Fiqih Lintas Agama, 158-159. 
Kritik atas Fikih Lintas Agama: Studi atas Pemikiran

Kaum Revivalis

Adapun terma al-musyrikât yang haram dinikahi seperti yang tertera dalam QS al-Baqarah/2: 221 menurut Tim Penulis Paramadina, tidak serta merta tertuju kepada musyrik dalam artian non-muslim (Nasrani atau Yahudi), karena kata syirik dalam al-Quran ditujukan kepada mereka yang kepercayaannya didasarkan pada perbuatan syirik, seperti meyakini 'Îsâ alMasîh sebagai putra Maryam (QS al- Mâidah/5: 17), mereka yang meyakini bahwa Allah adalah trinitas (QS al-Mâidah/5: 73) dan orang Yahudi yang menyatakan bahwa 'Uzair adalah anak Allah (QS al-Mâidah/5: 30). Akan tetapi, meskipun mereka melakukan perbuatan syirk, al-Quran tidak langsung menjustifikasi dan mengklaim mereka sebagai "musyrik", melainkan al-Quran menyebut mereka sebagai ahl al-kitâb sebagaimana termaktub dalam QS al-Nisâ/4: 171, QS al-Mâidah/5: 5 dan Âli Imrân/3: 64. Diksi kata yang diambil oleh al-Quran adalah kata ahl al-kitâb dan bukan kata musyrik. Menurut pemahaman Tim Penulis Paramadina, perbuatan syirik tidak serta merta membuat pelakunya disebut dengan musyrik. Syirik tidak hanya ditujukan kepada umat non Muslim yang menyekutukan Allah, tetapi bisa ditujukan kepada umat Muslim yang menyekutukan Allah. Penyekutuan Muslim kepada Allah bisa lewat berbagai bentuk dan cara, seperti mempertuhankan hawa nafsu, harta benda, ilmu, kedudukan dan lain sebagainya. Penyekutuan yang seperti ini selaras dengan firman Allah swt.: "Tidakkah engkau mengetahui orang-orang yang menjadikan hawa nafsunya sebagai Tuhannya" (QS al-Jâsyiyât/45: 23). Kalau seorang Muslim telah mempertuhankan harta atau hawa nafsu atau kedudukan lantas dihukumi sebagai kafir, berarti ikatan perkawinannya menjadi batal, dan hukumnya wajib cerai. Akan tetapi, fakta yang ada tidak demikian. Dengan demikian, QS al-Baqarah/2: 221 tentang pelarangan menikah dengan seorang musyrik jenis lain, bukan musyrik dalam artian melakukan perbuatan syirik, akan tetapi musyrik yang memiliki kriteria khusus, yaitu mereka yang suka memerangi orang-orang muslim dalam kehidupannya. ${ }^{26}$

Bentuk perkawinan ketiga, yaitu perkawinan dengan orang kafir disebutkan dalam QS al-Mumtahanah/60: 10, yaitu "Hai orang-orang yang beriman, apabila datang berhijrah kepadamu perempuan-perempuan yang beriman, maka hendaklah kamu uji (keimanan) mereka. Allah lebih mengetahui tentang keimanan mereka. Jika kamu mengetahui bahwa mereka (benar-benar) beriman, maka janganlah kamu kembalikan mereka kepada

${ }^{26}$ Nurcholish Madjid, et.al., Fiqih Lintas Agama, 161. 
(suami-suami mereka) orang-orang kafir. Mereka tiada halal bagi orangorang kafir itu dan orang-orang kafir itu tiada halal pula bagi mereka. Dan berikanlah kepada (suami suami) mereka, mahar yang telah mereka bayar. Dan tiada dosa atasmu mengawini mereka apabila kamu bayar kepada mereka maharnya. Dan janganlah kamu tetap berpegang pada tali (perkawinan) dengan perempuan-perempuan kafir. Dan hendaklah kamu minta mahar yang telah kamu bayar. Dan hendaklah mereka meminta mahar yang telah mereka bayar. Demikianlah hukum Allah yang ditetapkan-Nya di antara kamu. Dan Allah Maha mengetahui lagi Maha Bijaksana". Ayat ini berisi dua bentuk larangan. Pertama, mengembalikan wanita yang telah masuk Islam kepada suami mereka yang masih kafir. Pasca hijrah, mereka menyatakan keislamannya, sementara suaminya masih dalam kekafiran. Ayat ini melarang agar wanita yang telah beriman jangan dikembalikan atau kembali- kepada suaminya. Sebab suaminya masih dalam keadaan kafir. Kedua, menikah dengan kaum kafir. Pernyataan al-Qurân, yaitu "mereka tidak halal bagi orang-orang kafir itu dan orang-orang kafir itu tidak halal bagi mereka" dipahami sebagai pernyataan yang sangat tegas tentang keharaman wanita muslimah menikahi laki-laki non-muslim. Demikian pula sebaliknya. $^{27}$

Perdebatan yang muncul adalah apakah non muslim (selain agama Islam) termasuk kategori kafir dalam ayat tersebut? Mayoritas pendapat ulama di Indonesia mengkategorikan non Muslim adalah kafir sehingga diharamkan kawin dengan mereka. Dalam fatwa MUI tahun 1980 dan 2005, ayat di atas menjadi dasar hukum atas keharaman pernikahan beda agama. Pendapat ini berbeda dengan pendapat yang dianut oleh Tim Penulis Paramadina. Menurut Zainun Kamal tidak ditemukan ayat-ayat al-Quran secara pasti dan eksplisit yang mengharamkan perempuan muslim kawin dengan laki-laki agama apapun selain hanya dari kaum kafir Quraisy. Ayat di atas hanya mengharamkan perempuan mukmin kawin dengan laki-laki musyrik Quraisy, dan bukan lainnya. ${ }^{28}$

Al-Quran sendiri menggunakan terma kafir untuk beragam kelompok, yakni kepada orang kafir sebelum kerasulan Muhammad; kepada orang kafir Mekah yang mengingkari Allah dan melecehkan Nabi saw.; kepada orang-orang yang ingkar terhadap nikmat Allah; kepada orang-orang yang mencari pertolongan dan perlindungan kepada selain Allah; kepada

\footnotetext{
${ }^{27}$ Sayyid Sâbiq, Fiqh al-Sunnah, Vol. 2 (Beirut: Dâr al-Fikr, 2008), 506-507.

${ }^{28}$ Zainun Kamal, "Menafsir Kembali Perkawinan Antar Umat Beragama," 159.
} 
Kritik atas Fikih Lintas Agama: Studi atas Pemikiran

Kaum Revivalis

orang-orang yang tidak mau mengambil pelajaran (i'tibâr) dan cinta dunia; dan kepada orang-orang yang munafik dan murtad. ${ }^{29}$ Berdasarkan identifikasi Tim Penulis Paramadina, atas al-Quran mereka menemukan tujuh jenis kafir, yaitu: Pertama, kafir (kufr) inkar, yakni kekafiran dalam arti pengingkaran terhadap terhadap eksistensi Tuhan, rasul-rasul-Nya dan seluruh ajaran yang mereka bawa. Kedua, kafir (kufr) juhud, yakni kekafiran dalam arti pengingkaran terhadap ajaran-ajaran Tuhan dalam keadaan tahu bahwa apa yang diingkari itu adalah benar. Ketiga, kafir munafik (kufr nifâq), yaitu kekafiran yang mengakui Tuhan, Rasul dan ajarannya dengan lidah tetapi mengingkarinya dengan hati, menampakkan iman dan menyembunyikan kekafiran. Keempat, kafir (kufr) syirik, berarti mempersekutukan Tuhan dengan menjadikan sesuatu, selain dari-Nya, sebagai sembahan, obyek pemujaan, dan atau tempat menggantungkan harapan. Syirik digolongkan sebagai kekafiran sebab perbuatan itu mengingkari kekuasan Tuhan, juga mengingkari nabi-nabi dan wahyu-Nya. Kelima, kafir (kufr) nikmat, yakni tidak mensyukuri nikmat Tuhan dan menggunakan nikmat itu pada hal-hal yang tidak diridloiNya. Keenam, kafir murtad, kembali menjadi kafir sesudah beriman atau keluar dari Islam. Ketujuh, kafir Ahli Kitab, yakni non-Muslim yang percaya kepada nabi dan kitab suci yang diwahyukan Tuhan melalui nabi kepada mereka. ${ }^{30}$

Berdasarkan golongan dan jenis kafir di atas, Tim Penulis Paramadina menyimpulkan dua hal. Pertama, istilah kafir mencakup makna cukup luas yang di bawahnya terdapat istilah-istilah yang lebih khusus yang arti dan makna berbeda antara yang satu dari lainnya. Karena itu, jika Allah menyebutkan dalam al-Quran istilah kafir musyrik, maka itu maknanya mesti berbeda dengan makna istilah dari kata ahlul Kitâb. Tetapi jika disebutkan kata kafir saja, maka maknanya menunjuk kepada salah satu dari jenis-jenis kekafiran yang ada. Kedua, kafir musyrik berbeda dengan kafir ahlul Kitâb. Meskipun kaum Nasrani menyebut al-Masih putra Maryam adalah Tuhan (QS al-Taubah/9: 30) dan Allah yang ketiga dari trinitas (QS al-Mâidah/5: 73), dan kaum Yahudi menyebut Uzair putra Allah (QS alMaidah/5: 30), namun al-Quran tidak menyebut mereka dengan panggilan musyrik, meskipun perbuatan mereka adalah perbuatan syirik. Mereka tetap dipanggil Allah dengan sebutan ahl al-kitab (QS al-Nisâ/4: 171; QS al-

${ }^{29}$ M. Quraish Shihab, Ensiklopedi Al-Quran Kajian Kosa Kata dan Tafsirnya (Jakarta: Bimantara, 1997), 189-192.

${ }^{30}$ Nurcholish Madjid, et.al, Fiqh Lintas Agama, 156-157. 
Mâidah/5: 5 dan QS Âli Imrân/3: 64). ${ }^{31}$ Orang Islam pun bisa melakukan perbuatan syirik, dan kenyataannya ada, namun mereka tidak disebut sebagai kaum musyrik. Sebab sebagai konsekuensi logisnya, kalau salah seorang suami-istri dari keluarga muslim sudah disebut musyrik, maka perkawinan mereka batal dengan sendiri dan wajib cerai. Tetapi kenyataanya ini tidak pernah diterima. Betapa banyak terdapat dalam kenyataan hidup ini pada orang-orang beragama, termasuk orang-orang muslim melakukan perbuatan syirik dalam kehidupan sehari-harinya, seperti menjadikan dan menyembah tuhan-tuhan lain selain Allah (QS al-Nisâ/4: 36), mempertuhankan hawa nafsu, harta dan kedudukan (QS alJâtsiyyât/45: 23). Disinilah Tim Penulis Paramadina berpendapat bahwa pelaku-pelaku syirik ini tidak dikategorikan sebagai kaum musyrik, dan tidak diharamkan mengawini orang-orang Islam dikarenakan setiap perbuatan syirik tidak secara langsung menjadikan pelakunya sebagi musyrik, tetapi sebaliknya setiap orang musyrik sudah jelas pelaku syirik. ${ }^{32}$

Adapun tentang isu kewarisan beda agama telah ditegaskan hukumnya dalam kitab-kitab fikih, termasuk dalam Kompilasi Hukum Islam (KHI). Bahwa seorang muslim tidak boleh mewarisi orang kafir; demikian pula sebaliknya. Dengan kata lain, salah satu kelompok yang diharamkan untuk menerima dan memberi warisan (mawâni" al-irtsi) adalah orang kafir. Pendapat ini didasarkan QS al-Nisa/4: 141 bahwa "Dan Allah tidak memberikan jalan kepada orang-orang kafir untuk menundukkan (memusnahkan) orang-orang mukmin" dan hadis Nabi saw. bahwa "Seorang muslim tidak mewarisi kepada orang-orang kafir, begitu pula orang kafir tidak mewarisi kepada orang muslim." 33 Menurut Ibnu Rusyd bahwa sebagian besar ulama melarang atau mengharamkan waris beda agama, terutama berdasarkan ayat dan hadis ini. ${ }^{34}$ Itu berarti ada juga ulama yang membolehkan waris beda agama. Sedangkan menurut Tim Penulis Paramadina dalam konteks ini ada dua pendapat. Pertama, pendapat yang melarang kewarisan beda agama. Pendapat ini mengharamkan secara mutlak seorang muslim mewarisi non muslim; demikian pula sebaliknya. Karena itu, kelompok ini menolak waris beda agama. Pendapat pertama ini didasarkan

${ }^{31}$ Nurcholish Madjid, et.al, Fiqh Lintas Agama, 157-158.

${ }^{32}$ Nurcholish Madjid, et.al, Fiqh Lintas Agama, 159.

${ }^{33}$ Nurcholish Madjid, et.al, Fiqh Lintas Agama, 165.

${ }^{34}$ Al-Imam al-Qadhi Abu al-Walid Muhammad Ahmad ibn Muhammad ibn Ahmad ibn Rushd al-Qurthuby al-Andalusy, Bidayat al-Mujtahid wa Nihayat akMuqtashid, Jil. II (Dar al-Fikr, t.th), 264. 
Kritik atas Fikih Lintas Agama: Studi atas Pemikiran

Kaum Revivalis

atas ayat dan hadis di atas. Dalam fikih, mazhab Syafi'i termasuk kelompok ini. Kedua, pendapat yang membolehkan seorang muslim mewarisi nonmuslim dan dan mengharamkan kebalikannya. Pendapat kedua didasarkan atas penalaran analogi (qiyas) tentang kebolehan menikah dengan ahl alkitab, sebagaimana termaktub dalam QS al-Maidah/5: 5. Dengan ungkapan lain, jika pernikahan seorang Muslim dengan wanita non-Muslim (ahl alkitab) diperbolehkan, maka kewarisan pun dapat dibolehkan. Pendapat kedua ini dianut oleh antara lain Mu'adz ibn Jabal, Mu'awiyah, Sa'id ibn alMusayyah dan Masruq. ${ }^{35}$ Menurut Tim Penulis Paramadina pendapat kedua mencerminkan upaya para ulama terdahulu untuk mencari jalan alternatif dalam kaitannya dengan agama lain, seperti dalam hal kewarisan beda agama. Hanya saja disayangkan pendapat alternatif ini cenderung dilupakan atau dihilangkan begitu saja. Sebaliknya yang tersosialisasikan pendapat mayoritas (jumhur ulama). Padahal pendapat kedua lebih membela hak-hak minoritas, meskipun pendapat ini adalah pendapat minoritas. Pendapat kedua ini yang memberi ruang waris beda agama sejatinya diapresiasi, tidak saja lebih akomodatif terhadap non muslim, tetapi karena mempunyai landasan normative yang sangat kuat. ${ }^{36}$

Bukti adanya pendapat kedua ini menunjukan bahwa hal-hal yang dilarang dalam hak waris (mawâni" al-irtsi) bukan merupakan hal yang baku dan absolut. Sewaktu-waktu hukum tersebut bias berubah sesuai dengan konteks yang berbeda. Dulu, takkala hukum waris ini turun, memang harus diakui adanya kekhawatiran dan ketakutan terhadap non muslim. Kenyataan sebenarnya bukan hanya perbedaan agama, melainkan perbedaan kepentingan politik antara komunitas muslim dan non muslim. ${ }^{37}$ Agaknya Tim Penulis Paramadina memahami bahwa pelarangan waris beda agama tersebut lebih bersifat politis daripada teologis. Buktinya takkala Hudzaifah menikahi wanita ahl al-kitab dan Umar ibn al-Khaththab mencoba melarangnya, ia berkata: "Saya tidak melarang pernikahan tersebut, tapi saya khawatir dan takut...." Menurut Tim Penulis Paramadina, ucapan Umar ibn al-Khaththab ini sebetulnya bukan sebagai fatwa keagamaan, akan tetapi lebih tepat disebut sebagai sikap politis. ${ }^{38}$

Apalagi ayat yang menjadi dasar pendapat pertama yang melarang

\footnotetext{
${ }^{35}$ Nurcholish Madjid, et.al, Fiqh Lintas Agama, 166.

${ }^{36}$ Nurcholish Madjid, et.al, Fiqh Lintas Agama, 166.

${ }^{37}$ Nurcholish Madjid, et.al, Fiqh Lintas Agama, 166.

${ }^{38}$ Nurcholish Madjid, et.al, Fiqh Lintas Agama, 167.
} 
waris beda agama tidak menunjuk langsung pada pengharaman waris beda agama. Sedangkan hadis yang menjadi dasar normatif pun lebih bersifat umum. Oleh karena itu menurut Tim Penulis Paramadina, ayat tersebut tidak serta merta bisa dijadikan landasan untuk melarang waris beda agama. Bahkan dalam banyak ayat, Tuhan justru mengakomodasi agama-agama langit (Kristen, Yahudi, dan Shabi'ah) dan mereka yang beramal saleh. Mereka pun akan mendapatkan surga di hari kiamat nanti (QS al-Baqarah/2: $62) .{ }^{39}$

Tim Penulis Paramadina berpendapat hukum waris tersebut sejatinya harus dikembalikan pada semangat awalnya, yaitu dalam konteks keluarga ( ̂llu al-arhâm), keturunan (nasab), dan menantu (shakhr). Apapun agamanya yang menjadi tujuan utama adalah mempererat hubungan keluarga. Logikanya bila Islam menghargai agama lain dan mempersilahkan pernikahan dengan agama lain, maka secara otomatis waris beda agama diperbolehkan. Olehnya hadis yang melarang waris beda agama harus dibaca dalam semangat zaman, yang mana terdapat hubungan kurang sehat dengan agama lain (kafir). Bila hubungan muslim dengan non muslim dalam keadaan normal dan kondusif, maka secara otomatis matan hadis tersebut tidak bisa digunakan. ${ }^{40}$

Itu berarti larangan waris beda agama dalam hadis di atas dipahami oleh Tim Penulis Paramadina sebagai larangan dalam konteks tertentu. Dalam hal ini, larangan tersebut menunjukan adanya hubungan yang tidak kondusif antara kaum muslim dan non muslim. Dengan kata lain, illat (sebab hukum) atas pelarangan tersebut adalah kondisi yang sehat antara muslim dan non muslim. Kini kondisi tersebut sudah tidak ada lagi, maka pelarangan tersebut sudah tidak berlaku lagi.

\section{Kritik Islam Revivalis atas Fikih Lintas Agama}

Kaum Islam revivalis atau revivalisme Islam adalah kelompok Islam yang cara beragama berorientasi kepada ketentuan fikih klasik secara ketat. Dengan kata lain paradigma mereka beragama adalah fikih oriented. Di antara ciri beragama yang berorientasi pada ketentuan fikih klasik adalah mengedepankan opini hukum mayoritas (jumhur al-ulama), dan cenderung tidak menerima pembaruan atas fikih klasik. Oleh karena itu bangunan

\footnotetext{
${ }^{39}$ Nurcholish Madjid, et.al, Fiqh Lintas Agama, 167.

${ }^{40}$ Nurcholish Madjid, et.al, Fiqh Lintas Agama, 167.
} 
Kritik atas Fikih Lintas Agama: Studi atas Pemikiran

Kaum Revivalis

pemikiran fikih kelompok revivalis adalah konstruksi fikih mazhab. Dengan kata lain, kritik mereka atas fikih lintas agama yang diusung oleh Tim Penulis Paramadina ditolak mereka karena bertentangan dengan ketentuan fikih klasik. Sebab seluruh ahli fikih sepakat atas ketidakbolehan bagi muslim dan muslimah menikah dengan orang kafir yang tidak memiliki kitab samawi atau semacamnya, seperti musyrik penyembah berhala, matahari dan lain-lain serta orang ateis yang tidak meyakini Tuhan. Dalilnya adalah QS al-Baqarah/2: 211. ${ }^{41}$ Wahbah al-Zuhailî berpendapat bahwa berdasarkan ayat ini, seorang muslim tidak boleh kawin dengan seorang perempuan musyrik, yaitu perempuan yang menyembah Allah bersama tuhan yang lain, seperti berhala, atau bintang-bintang, atau api atau binatang. Dalam konteks ini termasuk di dalamnya perempuan ateis atau materialis, yaitu orang yang mempercayai materi sebagai tuhan, serta dia mengingkari keberadaan Allah, dia juga tidak mengakui berbagai agama samawi, seperti ateis, eksistensial, al-Bahaiyyah dan al-Qadiyaniyyah. ${ }^{42}$

Selanjutnya Wahbah al-Zuhailî berpendapat bahwa pelarangan pernikahan tersebut disebabkan tidak adanya keharmonisan, ketenangan dan kerjasama di antara suami istri. Perbedaan akidah menumbuhkan rasa gelisah dan ketidaktenangan, dan perpecahan di antara suami istri, sehingga kehidupan rumah tangga yang seharusnya berdiri di atas landasan sayang, kasih dan cinta tidak menjadi tenteram, dan tidak dapat tercapai tujuannya berupa ketenangan dan kestabilan. Kecuali itu, ketiadaan rasa keimanan terhadap suatu agama membuat seorang perempuan mudah untuk melakukan pengkhianatan rumah tangga, kerusakan dan keburukan; membuat hilang rasa amanah, kelurusan, dan kebaikan dari dalam dirinya, karena dia mempercayai takhayul dan imjinasi, serta terpengaruh dengan hawa nafsu dan tabiat diri yang tidak etis. Karena tidak ada agama yang mengekangnya, dan tidak ada yang mendorongnya untuk beriman kepada Allah, hari kiamat, hisab dan hari kebangkitan. ${ }^{43}$

Meskipun mazhab Hanafî, Mâlikî, Syâfi'î dan Hanbalî membolehkan seorang muslim menikah dengan orang kafir yang tidak memiliki kitab samawi, seperti Yahudi dan Nasrani, namun mereka tidak membolehkan

${ }^{41}$ Muhammad Ibrâhim Jannatî, Durûs fî̀ al-Fiqh al-Muqâran, terj. Ibnu Alwi Bafaqih, et. al, Fiqh Perbandingan Lima Mazhab, Jilid III (Jakarta: Cahaya, 2007), 354.

${ }^{42}$ Wahbah al-Zuhailî, Al-Fiqh al-Islâmî wa Adillatuhu, terj. Abdul Hayyie alKattani, et. al., Fiqh Islam wa Adillatuhu, Jilid IX (Jakarta: Gema Insani Press, 2011), 147.

${ }^{43}$ Wahbah al-Zuhailî, Fiqh Islam wa Adillatuhu, Jilid IX, 148. 
muslimah menikah dengan mereka. ${ }^{44}$ Secara ijmak, perkawinan demikian diharamkan. Dalil yang menjadi rujukan adalah QS al-Baqarah/2: 221, yaitu: "Jangan kalian menikahkan orang-orang musyrik (dengan wanita-wanita mukmin) sebelum mereka beriman" dan QS al-Mumtahanah/60: 10, yaitu "Maka jika kamu telah mengetehui bahwa mereka (benar-benar) beriman, maka janganlah kalian kembalikan mereka kepada (suami- suami mereka) orang-orang kafir. Mereka tiada halal bagi orang-orang kafir itu dan orangorang kafir itu tiada halal pula bagi mereka”. Berdasarkan ayat tersebut dikehathui karena dalam perkawinan ini dikhawatirkan perempuan yang beriman jatuh dalam kekafiran. Biasanya suami mengajak istrinya untuk memeluk agamanya, dan biasanya perempuan mengikuti suami mereka karena terpengaruh dengan perbuatan suaminya, dan mengikuti mereka dalam agama mereka. Terlebih diakhir ayat QS al-Baqarah/2: 221 disebutkan: "mereka mengajak ke neraka." Maksudnya mereka mengajak para perempuan mukmin kepada kekafiran. Ajakan kepada kekafiran adalah ajakan kepada api neraka, karena kekafiran mendatangkan api neraka. Perkawinan perempuan mukmin dengan orang kafir merupakan sebab bagi ke arah yang haram. Ini adalah perkara yang haram. Meskipun bunyi teks ayat tersebut memaparkan tentang orang-orang musyrik, tetapi yang menjadi 'illat (sebab) adalah ajakan ke api neraka, mencakup semua orang kafir, maka hukum menjadi umum dengan keumuman 'illat. Tegasnya, berdasarkan ayat tersebut seorang muslimah tidak boleh menikah dengan orang laki-laki ahl al-kitab, sebagaimana dia juga tidak boleh menikah dengan orang Majusi. Agama memutus penguasaan orang kafir terhadap orang mukmin berdasarkan QS al-Nisâ/4: 141, yaitu: "Allah sekali-kali tidak akan memberi jalan kepada orang-orang kafir untuk memusnahkan orang-orang beriman." Jika orang kafir boleh menikah dengan perempuan mukmin, maka ada jalan baginya untuk mengajak kepada agamanya, dan ini tidak boleh. ${ }^{45}$

Kalau pun ulama sepakat atas kebolehan menikahi perempuan ahl alkitab, maka perempuan yang dimaksud adalah perempuan yang percaya terhadap agama samawi, seperti orang Yahudi dan Nasrani. Ahl al-kitab adalah para pemegang kitab Taurat dan Injil. Dalam konteks QS alMâidah/5: 5, perempuan tersebut adalah al-muhshanat, yaitu mereka menjaga kehormatannya, karena dalam perkawinan seperti ini terdapat rasa

\footnotetext{
${ }^{44}$ Muhammad Ibrâhim Jannatî, Durûs fî al-Fiqh al-Muqâran, 354.

${ }^{45}$ Wahbah al-Zuhailî, Fiqh Islam wa Adillatuhu, Jilid IX, 148.
} 
Kritik atas Fikih Lintas Agama: Studi atas Pemikiran

Kaum Revivalis

sayang dan cinta di antara suami-istri, serta menyebarkan rasa tenteram dan tenang. ${ }^{46}$ Menurut Wahbah al-Zuhailî kebolehan menikah dengan perempuan ahl al-kitab dan larangan menikah dengan perempuan musyrik, karena pernikahan dengan ahl al-kitab terdapat kesamaan keimanan pada beberapa prinsip asasi, dimulai dengan pengakuan terhadap Tuhan, keimanan kepada rasul dan hari kiamat, dengan segala hisab dan siksaan yang ada didalamnya. Adanya titik temu ini menyebabkan adanya komunikasi berdasarkan landasan ini, yang menjamin terciptanya kehidupan perkawinan yang biasanya lurus dengan mengharap keislaman perempuan tersebut karena secara general dia beriman dengan kitab-kitab para nabi dan rasul. ${ }^{47}$

Namun menurut mazhab Hanafî̀ dan Syâfi'î, serta Mâlikî dalam salah satu pendapatnya, seorang mukmin makruh menikah dengan perempuan ahlul Kitab dan ahlul dzimmah. Dalam mazhab Hanbalî, perkawinan dengan perempuan ahl al-kitab adalah makruh. Dalam riwayat dicertikan bahwa Umar ra. berkata kepada orang-orang yang kawin dengan ahl al-kitab, "Ceraikanlah mereka". Maka para sahabat menceraikan mereka, kecuali Khuzdaifah. Kemudian Umar ra. berkata kepadanya: "Ceraikanlah dia". Khuzdaifah berkata kepada Umar ra. "Apakah kamu bersaksi bahwa dia adalah haram?" Umar ra. kembali berkata kepadanya: "Dia adalah minuman keras. Ceraikanlah dia." Khuzdaifah kembali bertanya kepada Umar ra., "Apakah kamu bersaksi bahwa dia adalah haram?". Umar ra. menjawab: "Dia adalah minuman keras." Khuzdaifah kembali berkata: "Aku telah mengetahui bahwa ia adalah minuman keras, akan tetapi ia halal bagiku." Setelah lewat beberapa waktu, Khuzdaifah menceraikan istrinya. Lalu ada orang yang bertanya kepadanya: "Mengapa kamu tidak menceraikannya ketika Umar ra. memerintahkan hal itu kepadamu?" Khuzdaifah menjawab: "Aku tidak mau manusia melihat aku melakukan suatu perkara yang tidak selayaknya aku lakukan."

Mayoritas ulama di Indonesia mengharamkan nikah beda agama, meskipun ada juga yang membolehkan. ${ }^{49}$ Menurut M. Quraish Shihab

${ }^{46}$ Wahbah al-Zuhailî, Fiqh Islam wa Adillatuhu, Jilid IX, 148-149.

${ }^{47}$ Wahbah al-Zuhailî, Fiqh Islam wa Adillatuhu, Jilid IX, 148-149.

${ }^{48}$ Wahbah al-Zuhailî, Fiqh Islam wa Adillatuhu, Jilid IX, 148-149.

${ }^{49}$ Diantara mereka yang membolehkan Harun Nasution, Ahmad Azhar Basyir, Nazaruddin Latif dan Sayuti Thalib. Menurut Harun Nasution bahwa tidak ada teks yang secara tegas (sharih), baik dalam al-Quran maupun hadis mutawatir yang melarang perkawinan beda agama. Sebaliknya, menurut Nazaruddin Latif bahwa ketentuan Tuhan sudah jelas bahwa Islam tidak melarang seseorang pemuda/pria muslim menikah dengan 
kebolehan tersebut bersifat kondisional, yaitu dibolehkan sebagai jalan keluar kebutuhan mendesak ketika itu, dimana kaum muslim sering bepergian jauh melaksanakan jihad tanpa mampu kembali ke keluarga mereka, sekaligus untuk tujuan dakwah. ${ }^{50}$ Namun M. Quraish Shihab lebih cenderung kepada pendapat mayoritas yang melarang perkawinan beda agama dengan beberapa alasan, diantaranya kebolehan yang terdapat dalam QS al-Mâidah/5: 5 telah dibatalkan ketentuan legalnya oleh QS alBaqarah/2: 21, yaitu "Janganlah kamu menikahkan orang-orang musyrik pria (dengan wanita-wanita muslimah) sampai mereka (pria-pria musyrik itu) beriman." Itulah sebabnya Abdullâh ibn Umar ra. menegaskan: "Saya tidak mengetahui kemusyrikan yang lebih besar daripada kemusyrikan seseorang yang percaya bahwa Tuhannya adalah Isa atau salah seorang hamba Allah." Alasan lainnya rangkaian redaksi QS al-Mâidah/5: 5 di atas, telah mendahulukan penyebutan wanita-wanita mukminah atas wanita-wanita ahlul Kitab. Hal ini memberi isyarat bahwa mereka (wanita-wanita mukminah) yang harus didahulukan karena betapa pun persamaan agama dan pandangan hidup sangat membantu melahirkan ketenangan, bahkan sangat menentukan kelanggengan rumah tangga. Itulah sebabnya surat alMâidah ayat 5 di atas ditutup dengan ancaman barang siapa yang kafir sesudah beriman, maka hapuslah amalnya, dan seterusnya, merupakan peringatan kepada setiap yang makan, dan atau merencanakan perkawinan dengan mereka, agar berhati-hati jangan sampai hal tersebut mengantar

gadis/wanita beragama Katolik, Kristen, dan Yahudi sebagaimana termaktub dalam alQuran (surat al-Mâidah/5: 5). Hanya saja seorang penasehat perkawinan tidak akan menganjurkan perkawinan yang berlainan agama (interfaith marriage). Meskipun seorang laki-laki Islam diperbolehkan kawin dengan perempuan mana saja, namun menurut Sayuti Thalib ada batasannya. Diantara batasan itu seorang laki-laki muslim dilarang kawin dengan perempuan- perempuan tertentu. Menurut Ahmad Azhar Basyir kebolehan menikah dengan wanita Yahudi atau Nasrani (wanita Kitâbî) tersebut bukan bersifat mutlak, melainkan bersyarat. Yaitu mampu menyelamatkan kehidupan agamanya, agama anakanaknya, agama Islam, dan umat Islam pada umumnya. Lihat Ichtiyanto, Perkawinan Campuran dalam Negara Republik Indonesia (Jakarta: Badan Litbang Agama dan Diklat Keagamaan Departemen Agama RI, 2003), 120; Lihat pula Latif H. S. M., Kasus Jodoh dan Perkawinan (Jakarta: BP4 Pusat, 1973), 38; Sayuti Thalib, Hukum Kekeluargaan Indonesia (Jakarta: t.p., 1982), 51

${ }^{50}$ M. Quraish Shihab, Tafsir al-Mishbah Pesan, Kesan dan Keserasian Al-Quran, Vol. 3, (Jakarta: Lentera Hati, 1421 H/2001 M), 28-30. Lihat juga M. Quraish Shihab, Anda Bertanya M. Quraish Shihab Menjawab Berbagai Masalah Keislaman (Bandung: AlBayan, 2002), 220-222. 
Kritik atas Fikih Lintas Agama: Studi atas Pemikiran

Kaum Revivalis

mereka kepada kekufuran, karena akibatnya adalah siksa akhirat nanti. ${ }^{51}$

Pendapat yang sama tentang larangan perkawinan beda agama juga dikemukakan oleh Mahmud Yunus, Hasan Basri, Mahmuddin Sudin, dan Ahmad Sukarja. Menurut Mahmud Yunus, lelaki Muslim dilarang mengawini perempuan Majusi, watsani (penyembah berhala) dan Sâibah (penyembah bintang). ${ }^{52}$ Hasan Basri menyatakan Islam melarang perkawinan antar agama. ${ }^{53}$ Mahmouddin Sudin berpendapat bahwa sekarang ini tidak ada lagi ahl al-kitab sebagai yang dimaksudkan oleh QS alMâidah/5: 5, karena mereka telah syirik, mereka dikategorikan musyrik dan mengawini wanitanya adalah haram. ${ }^{54}$ Menurut Ahmad Sukarja, pelarangan nikah beda agama tidak hanya berlaku bagi lelaki muslim dengan perempuan ahl al-kitab, melainkan juga sebaliknya. Ahmad Sukarja menulis hukum perkawinan antara perempuan muslim dengan laki-laki Kristen, Katolik, Hindu, Budha, dan pemeluk kepercayaan non-Islam lainnya adalah mutlak haram. Perkawinan laki-laki muslim dengan perempuan Hindu dan Budha juga mutlak haram, karena perempuan Hindu dan Budha termasuk golongan musyrik. Sementara itu, perkawinan laki-laki muslim dengan perempuan Kristen dan Katolik hukumnya haram li sadd al-dzarî'ah. ${ }^{55}$ Menurut M. Quraish Shihab, larangan tersebut dilatarbelakangi oleh keinginan menciptakan "sakinah" dalam keluarga yang merupakan tujuan perkawinan Perkawinan baru akan langgeng dan tenteram jika terdapat kesesuaian pandangan hidup antara suami-istri. Jangankan perbedaan agama, perbedaan budaya bahkan tingkat pendidikan pun tidak jarang menimbulkan kesalahpahaman dan kegagalan perkawinan. ${ }^{58}$

Majelis Ulama Indonesia (MUI) dan ormas Islam termasuk kelompok yang melarang perkawinan beda agama. Pada tanggal 1 Juni 1980, MUI mengeluarkan fatwa berkaitan dengan kawin beda agama. Fatwa ini

${ }^{51}$ M. Quraish Shihab, Tafsir al-Mishbah, 28-30. Lihat juga M. Quraish Shihab, Anda Bertanya M. Quraish Shihab Menjawab Berbagai Masalah Keislaman, 220-222.

${ }^{52}$ Mahmud Yunus, Hukum Perkawinan dalam Islam Menurut Madzhab Syafi'i, Hanafi, Maliki dan Hanbali (Jakarta: PT. Hidakarya Agung, 1983), 50. 269-270.

${ }^{53}$ Ramlan Marjoned, KH. Hasan Basri 70 Tahun (Jakarta: Media Da"wah, 1990),

${ }^{54}$ Mahmouddin Sudin, Perkawinan antar Agama, Inferfait Marriage (Jakarta: Yayasan Keluarga Sejahtera, 1988), 32-34.

${ }^{55}$ Ahmad Sukarja, "Perkawinan Berbeda Agama Menurut Hukum Islam," dalam Chuzaimah dan Hafiz Anshary (ed.), Problematika Hukum Islam Kontemporer, Buku Pertama (Jakarta: LSIK, 1996), 1-16. 
menegaskan dua ketetapan. Pertama, bahwa seorang perempuan Islam tidak diperbolehkan untuk dikawinkan dengan seorang laki-laki bukan Islam. Kedua, bahwa laki-laki muslim tidak diizinkan mengawini seorang perempuan bukan Islam, termasuk Kristen (ahl al-kitab). Fatwa MUI ini sejalan dengan pandangan ormas Islam. Muhammadiyah secara resmi mengeluarkan ketetapan larangan dan keharaman nikah beda agama. Lakilaki muslim tidak dibenarkan mangawini perempuan musyrik, sedangkan perempuan muslimah juga tidak dibenarkan dikawinkan dengan laki-laki musyrik dan ahl al-kitab. Keharaman di sini bukan haram li dzâtihi, tetapi haram li sadd al-dzarî'ah. Metode ini dipandang sebagai bentuk aplikasi dari kaidah fikih: Dar'u al-mafâsid muqaddamun alâ jalbi al-mashâlihh (menghindari kerusakan itu harus lebih didahulukan daripada mengambil kemaslahatan). Dari sisi maqâshid al-syarî'ah (tujuan hukum), metode ini dimaksudkan untuk merealisasikan pemeliharaan atas agama ( Dengan alasan untuk menghindari perpindahan agama. ${ }^{56}$

Menurut Nahdhatul Ulama (NU), pernikahan lintas agama, semisal Islam dengan Kristen adalah tidak sah, karena orang Kristen tidak termasuk dalam kategori ahl al-kitab yang memenuhi syarat (boleh) dinikahi. Adapun syarat diperbolehkannya menikahi kafir kitabî adalah jika mereka dari kalangan Bani Israil, maka nenek moyangnya harus tidak masuk agama tersebut setelah di-nasakh (diganti). Kalau dari selain Bani Israil, maka harus diketahui bahwa nenek moyangnya masuk agama itu sebelum dinasakh, walaupun setelah terjadinya distorsi, dengan catatan ia menjauhi

\footnotetext{
${ }^{56}$ Majelis Tarjih dan Pengembangan Pemikiran Islam P.P. Muhammadiyah, Tafsir Tematik Al-Qur'an: tentang Hubungan Sosial Antar Umat Beragama (Yogyakarta: Pustaka SM, 2000), 219. Semula Muhammadiyah cenderung kepada pendapat yang membolehkannya berdasarkan kekhususan QS al-Mâidah/5: 5, sebab Nabi Muhammad sendiri pernah mengawini Maria Qibtiyah, seorang perempuan Nasrani dari Mesir. Sebagian sahabat Nabi juga ada yang kawin dengan perempuan ahl al-kitab, tetapi kemudian Muhammadiyah melarangnya. Alasannya hukum mubah (boleh) harus dihubungkan dengan alasan mengapa perkawinan itu dibolehkan. Salah satu hikmah (baca: "illat hukum) adalah untuk berdakwah kepada mereka, dengan harapan mereka bisa mengikuti agama suaminya (Islam). Jika keadaan justru sebaliknya, laki-laki muslim akan terbawa kepada agama ahlul Kitab, maka hukum mubah dapat berubah menjadi haram. Perubahan fatwa tersebut didasarkan atas realitas di tengah masyarakat bahwa nikah beda agama berdampak negatif. Pertama, beralihnya agama suami pada agama yang dianut oleh istrinya. Kedua, pada umumnya agama yang dianut anaknya sama dengan agama yang dianut ibunya. Atas dasar itu, dengan menggunakan metode sadd al-dzarîah, Muhammadiyah mengharamkan perkawinan laki-laki muslim dengan perempuan ahlul Kitab. Lihat Faturrahman Djamil, Metode Ijtihad Majlis Tarjih Muhammadiyah (Jakarta: Logos, 1995), 143-148.
} 
Kritik atas Fikih Lintas Agama: Studi atas Pemikiran

Kaum Revivalis

agama yang telah didistorsi itu. ${ }^{57}$ Oleh karena itu, tidak ada ruang bagi pernikahan beda agama di Indonesia, sebab UU No. 1 Tahun 1974 tentang Perkawinan (UUP), dan Inpres No. 1 Tahun 1991 tentang Kompilasi Hukum Islam (KHI) tidak mengakomodirnya. Di dalam KHI pasal 40 butir c, disebutkan: "Dilarang melangsungkan perkawinan antara seorang laki-laki dengan seorang perempuan karena keadaan tertentu: -diantaranya- (c) seorang perempuan yang tidak beragama Islam. Dalam KHI Pasal 44, disebutkan bahwa "Seorang perempuan Islam dilarang melangsungkan perkawinan dengan seorang laki-laki yang tidak beragama Islam. ${ }^{58}$ Pelarangan perkawinan beda agama ini menjadi lebih kuat karena UUP pasal 2 (1) menyebutkan bahwa perkawinan adalah sah, apabila dilakukan menurut hukum masing-masing agamanya dan kepercayaannya itu. ${ }^{59}$ Disamping itu juga merujuk UUP pasal 8 (f), yakni: Perkawinan dilarang antara dua orang yang: (f) mempunyai hubungan yang oleh agamanya atau peraturan lain berlaku, dilarang kawin. ${ }^{60}$

Adapun isu kewarisan beda agama, para imam mazhab sepakat atas keharaman kewarisan beda agama (non muslim) bahwa haram seorang muslim mewarisi harta orang kafir, demikian pula sebaliknya. ${ }^{61}$ Di antara alasan yang dikemukakan adalah sebagaimana yang dijelaskan Imam alSyafi'i yang menolak pemaknaan kata kâfirdengan kâfir harbî, ${ }^{62}$ karena menurut Imam al-Syafi'I, baik kafir ahl al-kitab maupun kafir penyembah berhala, baik kâfir harbî maupun kâfir dzimmî, tetap tidak diperbolehkan

${ }^{57}$ Tim Kajian Fikih Pondok Pesantren Sidogiri, Buku Besar Keputusan Bahtsul Masail Santri Salaf Menjawab Pandangan Kitab Kuning Mengenai Berbagai Persoalan Keagamaan, Kenegaraan dan Kemasyarakatan (Jawa Timur: Pustaka Sidogiri Benteng Ahlus Sunnah wal Jamaah, 1432 H), 657-658.

${ }^{58}$ Departemen Agama RI, Bahan Penyuluhan Hukum (Undang-undang Nomor 7 Tahun 1989 tentang Peradilan Agama, UU No. 1 Tahun 1974 tentang Perkawinan dan Inpres No. 1/1991 tentang Kompilasi Hukum Islam Indonesia) (Jakarta: Direktorat Jenderal Pembinaan Kelembagaan Agama Islam 1996/1997), 301-302.

${ }^{59}$ Departemen Agama RI, Bahan Penyuluhan Hukum, 290-291.

${ }^{60}$ Ahmad Sukarja, "Perkawinan Berbeda Agama Menurut Hukum Islam," 22-23.

${ }^{61}$ Muhammad Jawwad Mughniyah, Al-Fiqh alâ Madzhab Al-Khamsah (Kairo: Maktabah al- Fikrah, $1414 \mathrm{H}), 281$.

${ }^{62}$ Terminologi kâfir dzimmî dan kâfir harbî digunakan untuk mengklasifikasikan kalangan non- Islam; kafir dzimmi adalah kalangan non-Muslim yang mana hak-haknya sebagai manusia harus dijaga di tengah-tengah kalangan Muslim karena kondisi yang damai dan pembayaran jizyah (semacam pajak khusus bagi non-Muslim). Sendangkan kafir harbi adalah kalangan non-Muslim yang diperangi karena situasi dan kondisi perang di antara kedua belah pihak. 
muslim menerima waris darinya, karena mereka sama-sama kafir. Alasan yang lainnya adalah tidak adanya nash yang mentakhshish kata kâfir dalam hadis yang melarang Muslim dan kafir saling mawarisi. ${ }^{63}$ Senada dengan Syafi"i adalah pendapat Imam al-Syaukani yang menyatakan bahwa tidak ada pengecualian tentang makna kâfir kecuali dengan dalil yang tegas. ${ }^{64}$

Adapun mereka yang membolehkan waris beda agama dengan merujuk kepada riwayat dari Umar, Muadz, dan Muawiyah, menurut Ibnu Qudamah bahwa riwayat tersebut tidak bisa dipercaya. Sebab Imam Ahmad mengatakan bahwa tidak ada perbedaan pendapat bahwa Muslim tidak mewarisi dan mewariskan harta orang kafir. Yang dipraktekkan oleh kebanyakan fukaha adalah perbedaan agama antara Islam dan kafir menghalangi warisan dari kedua pihak. Begitu pula mereka sepakat bahwa kafir yang seagama boleh saling mewarisi di antara mereka apabila mereka berada dalam satu negara. Adapun seorang murtad yang memeluk agama Islam sebelum harta waris dibagikan, maka berhak baginya mendapatkan bagian. Ibnu Qudamah berpendapat bahwa hadis shahih harus didahulukan daripada riwayat yang tidak disepakati keshahihannya. ${ }^{65}$ Agaknya kesahihan riwayat dari Umar, Mu'adz, dan Mu'awiyah tidak disepakati ulama, sehingga sebaiknya ditinggalkan dan lebih mengutamakan riyawat yang disepakati kesahihannya. Riwayat tentang larangan muslim mewarisi non muslim disepakati kesahihannya.

Menurut Musthafa al-Salabiy bahwa nash (teks) tentang larangan waris beda agama adalah jelas dan qath'i bahwa tidak saling mewarisi antara orang muslim dengan non-muslim, dan demikian sebaliknya. ${ }^{66}$ Syekh Muhammad Ali al-Shabuni memasukkan perbedaan agama antara muslim dengan non-muslim menjadi salah satu penghalang kewarisan (mawâni' alirts). ${ }^{67}$ Hal ini juga dikemukakan Sayyid Sabiq dalam Fiqh al-Sunnah. ${ }^{68}$ Pendapat ini diikuti MUI yang melarang waris beda agama dengan alasan

\footnotetext{
${ }^{63}$ Muhammad bin Idris al-Syafi'i, Al-Umm (Beirût: Dâr al- Fikr, 1403 H), 76-77.

${ }^{64}$ Muhammad al-Syaukani, Nailul Awthâr (Kairo: Maktabah Al-Salafiyah, 1374 H), 2085

${ }^{65}$ Abu Muhammad Abdulah bin Ahmad Ibnu Qudamah, Al-Mughni, Jilid VII (Beirût: Dâr al-Fikr, 1404 H), 166.

${ }^{66}$ Ahmad Musthafa Al-Salabiy, Ahkâm al-Mawârits (Beirût: Dâr al-Nahdhah alArabiyah, 1978), 87-92.

${ }^{67}$ Muhammad Ali Al-Shabuni, Al-Mawârits fî al-Syari'ah al-Islâmiyah (Beirût: Dâr al-Qalam, 1409 H/1989 M), 32.

${ }^{68}$ Sayyid Sabiq, Fiqih Sunnah, Jilid 4 (Kairo: Dâr al-Fath, 2004), 486.
} 
Kritik atas Fikih Lintas Agama: Studi atas Pemikiran

Kaum Revivalis

bahwa adanya teks tentang hukum waris Islam tidak memberikan hak saling mewarisi antar orang-orang yang berbeda agama (antara muslim dengan non-muslim). Namun pemberian harta antara orang yang berbeda agama dapat dilakukan dalam bentuk hibah, wasiat, dan hadiah; dan bukan melalui institusi kewarisan. ${ }^{69}$ Adanya kritikan kaum revivalis terhadap pandangan Tim Penulis Paramadina dalam kasus perkawinan beda agama dan kewarisan beda agama dikarenakan adanya perbedaan pemahaman terhadap nash-nash yang dijadikan patokan terhadap kedua kasus tersebut.

\section{Penutup}

Pendapat Fiqih Lintas Agama yang digagas Tim Penulis Paramadina tentang kebolehan perkawinan beda agama dan kewarisan beda agama tanpa membedakan apakah ahl al-kitab, musyrik dan kafir lebih didasarkan atas paradigma fikih yang inklusif, yaitu fikih yang berorientasi kepada akomodasi hak-hak minoritas. Akomodasi fikih ini didasarkan atas dua argumen: teologis-normatif dan historis. Secara teologis-normatif, perkawinan beda agama (dalam konteks ahl al-kitab) dibolehkan dalam QS al-Mâidah/5: 5. Adapun larangan yang termaktub dalam QS al-Baqarah/2: 221 (kawin dengan kaum musyrik), dan QS al-Mumtahanah/60: 10 (kawin dengan orang kafir) bersifat kontekstual-politis daripada teologis. Sedangkan kebolehan waris beda agama didasarkan atas riwayat yang bersumber dari Mu'adz dan Mu'awiyah, yang kemudian diikuti oleh sebagian ulama kontemporer seperti Yusuf al-Qardhawi. Riwayat tersebut dalam pandangan revivalisme Islam adalah tidak disepakati kebenarannya alias diragukan. Sedangkan teks tentang larangan waris beda agama adalah jelas dan tegas.

Larangan menikah dengan kaum musyrik dan kafir bahwa secara tekstual boleh menikah dengan ahl al-kitab, namun dampak negatifnya lebih besar daripada manfaatnya. Oleh karena itu, mayoritas mengharamkannya. Keharaman tersebut bersifat sad al-dzariah, dan bukan karena adanya teks yang menunjukkannya. Ini berbeda kasus perkawinan dengan kelompok musyrik dan kafir, yang dengan tegas disebutkan dalam QS al-Baqarah/2: 221 (larangan menikah dengan kaum musyrik) dan QS al-Mumtahanah/60: 10 (larangan menikah dengan orang kafir). Demikian jelas dan tegas

\footnotetext{
${ }^{69}$ MUNAS VII MUI 2005, Keputusan Fatwa MUI No: 5/ MUNAS VII/MUI/9/2005.
} 
sehingga tidak menimbulkan interpretasi ganda; dan karenanya mayoritas ulama melarang termasuk MUI, NU dan Muhammadiyah, UUP dan KHI.

Terkait isu waris beda agama, Pendapat mayoritas ulama fikih dan ketentuan hukum positif di Indonesia (UUP dan KHI) juga tidak membuka ruang sehingga tidak dapat diterapkan, karena dalil normatif tentang kebolehan waris beda agama yang disandarkan kepada riwayat $\mathrm{Mu}$ 'dz dan Mu'awiyah dinilai sebagai riwayat yang tidak disepakati kevalidannya. Ini berbeda dengan hadis tentang larangan seorang muslim mewarisi orang kafir; dan demikian sebaliknya adalah dalil yang disepakti kevalidannya. Dalam perspektif revivalisme Islam atau Islam revivalis mendahulukan dalil yang disepakti kevalidannya adalah lebih utama diperpegangi daripada dalil yang tidak disepakti kevalidannya. Demikian juga memilih pendapat mayoritas atas pendapat minoritas jauh lebih dikedepankan.

\section{Daftar Pustaka}

Al-Andalusy, Al-Imam al-Qadhi Abu al-Walid Muhammad Ahmad ibn Muhammad ibn Ahmad ibn Rushd al-Qurthuby. Bidayat alMujtahid wa Nihayat ak-Muqtashid, Jil. II. Dar al-Fikr, t.th.

Departemen Agama RI. Bahan Penyuluhan Hukum (Undang-undang Nomor 7 Tahun 1989 tentang Peradilan Agama, UU No. 1 Tahun 1974 tentang Perkawinan dan Inpres No. $1 / 1991$ tentang Kompilasi Hukum Islam Indonesia). Jakarta: Direktorat Jenderal Pembinaan Kelembagaan Agama Islam 1996/1997.

Djamil, Faturrahman. Metode Ijtihad Majlis Tarjih Muhammadiyah. Jakarta: Logos, 1995.

Eoh O.S. Perkawinan Beda Agama dalam Teori dan Praktek. Jakarta: Raja Grafindo Persada,1996.

Hadikusuma, Hilman. Hukum Perkawinan Indonesia Menurut Perundangan, Hukum Adat, Hukum Agama. Bandung: Mandar Maju, 1990.

Ibnu Qudamah, Abu Muhammad Abdulah bin Ahmad. Al-Mughni, Jilid VII (Beirût: Dâr al-Fikr, 1404 H.

Ibnu Rusyd, Bidayah al-Mujtahid wa Nihayah al-Muqtashid, Jil. II. Beirut: Dar al-Fikr, t.th.

Ibnu Taimiyah. Ahkkam al-Zawâj. Beirût: Dâr al-Kutub al-Ilmiyyah, $1408 \mathrm{H} / 1988 \overline{\mathrm{M}}$. 
Kritik atas Fikih Lintas Agama: Studi atas Pemikiran

Kaum Revivalis

Ichtiyanto. Perkawinan Campuran dalam Negara Republik Indonesia. Jakarta: Badan Litbang Agama dan Diklat Keagamaan Departemen Agama RI, 2003.

Islamiyati. "Analisis Yuridis Nikah Beda Agama Menurut Hukum Islam di Indonesia," Masalah-Masalah Hukum, Jilid 45 No. 3, Juli 2016.

Jaiz, Hartono Ahmad. "Kata Pengantar" dalam Agus Hasan Bashori, Koreksi Total Fiqh Lintas Agama Membongkar Kepalsuan Paham InklusifPluralis. Jakarta: Pustaka Al-Kautsar, 2004.

Jannatî, Muhammad Ibrâhim. Durûs fî al-Fiqh al-Muqâran, terj. Ibnu Alwi Bafaqih, et. al, Fiqh Perbandingan Lima Mazhab, Jilid III. Jakarta: Cahaya, 2007.

Kamal, Zainun. "Menafsir Kembali Perkawinan Antar Umat Beragama" dalam Maria Ulfah Anshor dan Martin Lukito Sinaga (eds.), Tafsir Ulang Perkawinan Lintas Agama Perspektif Perempuan dan Pluralisme (Jakarta: Kapal Perempuan, 2005.

Latif H. S. M. Kasus Jodoh dan Perkawinan. Jakarta: BP4 Pusat, 1973.

Madjid, Nurcholish, et. al. Fiqh Lintas Agama Membangun Masyarakat Inklusif-Pluralis. Jakarta: Yayasan Wakaf Paramadina - The Asia Foundation, 2004.

. Islam Agama Peradaban Membangun Makna dan Relevansi Doktrin Islam dalam Sejarah. Jakarta: Paramadina, 1995.

Majelis Tarjih dan Pengembangan Pemikiran Islam P.P. Muhammadiyah, Tafsir Tematik Al-Qur'an: tentang Hubungan Sosial Antar Umat Beragama. Yogyakarta: Pustaka SM, 2000

Mughniyah, Muhammad Jawwad. Al-Fiqh alâ Madzhab Al-Khamsah. Kairo: Maktabah al- Fikrah, $1414 \mathrm{H}$.

Mulia, Siti Musdah. Islam dan Inspirasi Kesetaraan Gender. Yogyakarta: Kibar Press, 2007.

MUNAS VII MUI 2005. Keputusan Fatwa MUI No: 5/MUNAS $\mathrm{VII} / \mathrm{MUI} / 9 / 2005$.

Rachman, Budy Munawar. Reorientasi Pembaruan Islam: Sekularisme, Liberalisme \& Pluralisme Paradigma Baru Islam Indonesia. Jakarta: LSAF, 2010. 
Ramlan Marjoned, KH. Hasan Basri 70 Tahun. Jakarta: Media Da’wah, 1990.

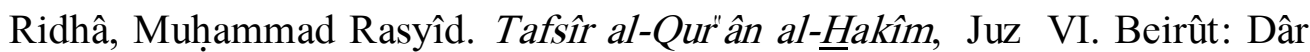
al- Kutub al-'Ilmiyyah, 1999 M.

Sâbiq, Sayyid. Fiqh al-Sunnah, Vol. 2. Beirut: Dâr al-Fikr, 2008.

. Fiqih Sunnah, Jilid 4. Kairo: Dâr al-Fath, 2004.

Al-Salabiy, Ahmad Musthafa. Ahkâm al-Mawârits. Beirût: Dâr al-Nahdhah al-Arabiyah, 1978.

Al-Shabuni, Muhammad Ali. Al-Mawârits fî al-Syari'ah al-Islâmiyah. Beirût: Dâr al-Qalam, 1409 H/1989 M.

Al-Shâliba, Jamîl. Min Aflatan ilâ Ibn Sînâ. Beirût: Dâr al-Andalus, 1981.

Al-Shan'ânî, Subul al-Salâm, Juz III. Bandung: Dahlan, t.th.

Shihab, M. Quraish. Anda Bertanya M. Quraish Shihab Menjawab Berbagai Masalah Keislaman. Bandung: Al-Bayan, 2002.

. Ensiklopedi Al-Quran Kajian Kosa Kata dan Tafsirnya. Jakarta: Bimantara, 1997.

. Tafsir al-Mishbah Pesan, Kesan dan Keserasian Al-Quran, Vol. 3. Jakarta: Lentera Hati, 1421 H/2001 M

. Anda Bertanya M. Quraish Shihab Menjawab Berbagai Masalah Keislaman. Bandung: Al-Bayan, 2002.

Sudin, Mahmouddin. Perkawinan antar Agama, Inferfait Marriage. Jakarta: Yayasan Keluarga Sejahtera, 1988.

Sukarja, Ahmad. "Perkawinan Berbeda Agama Menurut Hukum Islam," dalam Chuzaimah dan Hafiz Anshary (ed.), Problematika Hukum Islam Kontemporer, Buku Pertama. Jakarta: LSIK, 1996.

Al-Syafi'i, Muhammad bin Idris. Al-Umm. Beirût: Dâr al- Fikr, 1403 H.

Syarifuddin, Amir. Hukum Perkawinan Islam di Indonesia. Kencana Prenada Media Group, Jakarta, 2009.

Al-Syaukani, Muhammad. Nailul Awthâr. Kairo: Maktabah Al-Salafiyah, $1374 \mathrm{H}$. 
Kritik atas Fikih Lintas Agama: Studi atas Pemikiran

Kaum Revivalis

Thalib, Sayuti. Hukum Kekeluargaan Indonesia. Jakarta: t.p., 1982.

Tim Editor Mujahidin. Kekafiran Berpikir Sekte Paramadina. Jakarta: Wihdah Press, 2004.

Tim Kajian Fikih Pondok Pesantren Sidogiri. Buku Besar Keputusan Bahtsul Masail Santri Salaf Menjawab Pandangan Kitab Kuning Mengenai Berbagai Persoalan Keagamaan, Kenegaraan dan Kemasyarakatan. Jawa Timur: Pustaka Sidogiri Benteng Ahlus Sunnah wal Jamaah, $1432 \mathrm{H}$.

Yunus, Mahmud. Hukum Perkawinan dalam Islam Menurut Madzhab Syafi'i, Hanafi, Maliki dan Hanbali. Jakarta: PT. Hidakarya Agung, 1983.

Al-Zuhailî, Wahbah. Al-Fiqh al-Islâmî wa Adillatuhu, terj. Abdul Hayyie alKattani, et. al., Fiqh Islam wa Adillatuhu, Jilid IX. Jakarta: Gema Insani Press, 2011. 